\title{
Evaluation of the Effect of the Intensity and Occurrence of Postoperative Pain of Resin-Based and Bioceramic Root Canal Sealers: A Systematic Review and Meta-Analysis of Randomized Controlled Trial Studies
}

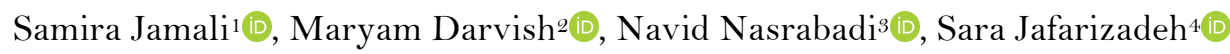

\begin{abstract}
'Department of Endodontics, Stomatological Hospital, College of Stomatology, Xi'an Jiaotong University, Shaanxi 710004, PR China.
${ }^{2}$ Department of Endodontics, School of Dentistry, Kerman University of Medical Sciences, Kerman, Iran.

${ }^{3}$ Department of Endodontics, School of Dentistry, Shahid Beheshti University of Medical Sciences, Tehran, Iran.

${ }^{4}$ School of Dentistry, Islamic Azad University, Tabriz Branch, Tabriz, Iran.
\end{abstract}

Correspondence: Samira Jamali, Department of Endodontics, Stomatological Hospital, College of Stomatology, Xi'an Jiaotong University, Shaanxi 710004, PR China. E-mail: samira.jamali90@yahoo.com

Academic Editor: Yuri Wanderley Cavalcanti

Received: 10 October 2020 / Review: 22 December 2020 / Accepted: 20 January 2021

How to cite: Jamali S, Darvish M, Nasrabadi N, Jafarizadeh S. Evaluation of the effect of the intensity and occurrence of postoperative pain of resin-based and bioceramic root canal sealers: a systematic review and meta-analysis of randomized controlled trial studies. Pesqui Bras Odontopediatria Clín Integr. 202 1; $21:$ :e219. https://doi.org/10.1590/pboci.2021.082

\begin{abstract}
Objective: To evaluate resin- and bioceramic root canal sealers affect postoperative intensity and pain occurrence. Material and Methods: From the electronic databases, PubMed, Cochrane Library, Embase, ISI have been used to perform systematic literature until September 2020. Electronic titles were managed using the Endnote X8 software. They performed searches with mesh terms. Two reviewers blindly and independently extracted data from studies that included data for data extraction. Results: A total of 186 potentially relevant titles and abstracts were found. Finally, four studies were included. Pain score was (RR $=-0.20 ; 95 \% \mathrm{CI}-1.09-0.68 ; \mathrm{p}=0.65)$. This result showed no statistically significant difference for the resinbased and bioceramic root canal sealers after 24 hours between the VAS scores. Conclusion: Postoperative pain was low in Patients requiring root canal retreatment and obturated with resin-based or bioceramicbased sealers without extrusion beyond the apex. No differences were observed between postoperative pain in resin-based and bioceramic root canal sealers 24 and 48 hours postoperatively.
\end{abstract}

Keywords: Endodontics; Root Canal Filling Materials; Pain, Postoperative. 


\section{Introduction}

Studies have shown that endodontic postoperative pain between 3 to $58 \%$ [1-3]. Pain may occur in periodontal tissues after mechanical, chemical, and microbiological injuries [4]. There are various parameters in treatment that can cause postoperative pain. One of these parameters is including working length (WL). Also, the number of visits, selection of instruments, and the selection of root canal sealers are other related parameters [5-7].

Sealers placed in the root canals and interact with the periodontal tissues through the apical perforation, lateral canals, or leaching can affect the periodontium's healing process. As a result, postoperative pain is caused by local inflammation of the root canal [8].

Bioceramic materials can help endodontic treatment by releasing biologically active substances and promoting odontoblasts' differentiation [9-12]. In vitro studies have shown that bioceramic materials were less cytotoxic than resin-based materials [13-16]. Other studies have also shown that resin-based have stronger bonding capacity and higher radiopacity than bioceramic materials [17,18]. Graunaite et al. [19], in a split-mouth randomized controlled trial, showed resin-based sealer (AH Plus) and Total Fill had a similar occurrence and intensity of postoperative pain.

Given that the exact results are not noticeable, and a systematic review and meta-analysis studies have not been performed in this field, the researcher decided to review the results of RCT studies; the aim of this study is to evaluate the effect of resin-based and bioceramic root canal sealers on postoperative pain intensity and occurrence.

\section{Material and Methods}

Search Strategy

From the electronic databases, PubMed, Cochrane Library, Embase, ISI have been used to perform systematic literature over the last five years between 2015 to September 2020. Endnote X8 software was used to manage electronic titles. Searches were performed using mesh terms: ("Dental Pulp Cavity" $[$ Mesh] OR "Root Canal Therapy"[Mesh] OR "Root Canal Filling Materials"[Mesh〕) OR "Endodontics"[Mesh]) AND "iRoot BP Plus" [Supplementary Concept]) AND "epoxy resin-based root canal sealer" [Supplementary Concept]) AND "Pain, Postoperative"[Mesh].

This study is based on the Systematic Review and Meta-Analysis (PRISMA) Statement-Preferred Reporting Items [20] and the PICO or PECO Strategy (Table1).

Table 1. PICO OR PECO strategy.

\begin{tabular}{cc}
\hline PICO OR PECO Strategy & Description \\
\hline $\mathrm{P}$ & Population/ Patient: Patients requiring root canal retreatment \\
$\mathrm{E}$ & Exposure/ Intervention: Resin-based sealer (AH Plus) / Total Fill BC \\
$\mathrm{C}$ & Comparison: AH Plus vs. Bioceramic-based sealers \\
$\mathrm{O}$ & Outcome: Postoperative Pain Scores \\
\hline
\end{tabular}

\section{Selection Criteria}

The following inclusion criteria were adopted: 1) Randomized controlled trial studies, controlled clinical trials, and prospective and retrospective cohort studies; 2) Used AH Plus; 3) Used bioceramic root canal sealers; 4) Patients requiring root canal retreatment; 5) VAS scale; and 6) In English.

Regarding the exclusion criteria, the following were established: 1) Periapical lesions; 2) Studies carried out in vitro, case reports, case studies, and reviews; and 3) Animal studies. 


\section{Data Extraction and Method of Analysis}

The data were extracted from the research that included information about the study, years, study design, sample size, mean/ range of age, number of teeth, scale, root canal sealers, and follow-up period. The quality of the included studies has been evaluated using the tool of Cochrane Collaboration [21]. The scale scores for low risk were 1 and for High and unclear risk was 0. Scale scores range from o to 6. A higher score means higher quality. Two reviewers blinded and extracted data independently for data extraction of studies that included.

Moreover, the risk ratio between two groups (resin-based and bioceramic root canal sealers), the model for random effect and the method for restricted maximum likelihood (REML) were calculated with a 95\% confidence interval (CI). Random effects were used to resolve the potential heterogeneity, and $\mathrm{I}^{2}$ showed heterogeneity. Stata Statistical Software, V.16 (StataCorp LLC., TX, USA) was used in meta-analysis.

\section{Results}

According to the research design, 186 potentially important research abstracts and titles have been discovered in our electronic searches. In the first phase of the study selection, 156 research has been about the topics and abstracts. Therefore, we thoroughly assessed the complete full-text papers of the rest 28 studies in the second stage to exclude 24 publications due to the lack of the defined inclusion criteria. Then, four papers remained in agreement with our inclusion criteria required (Figure 1).

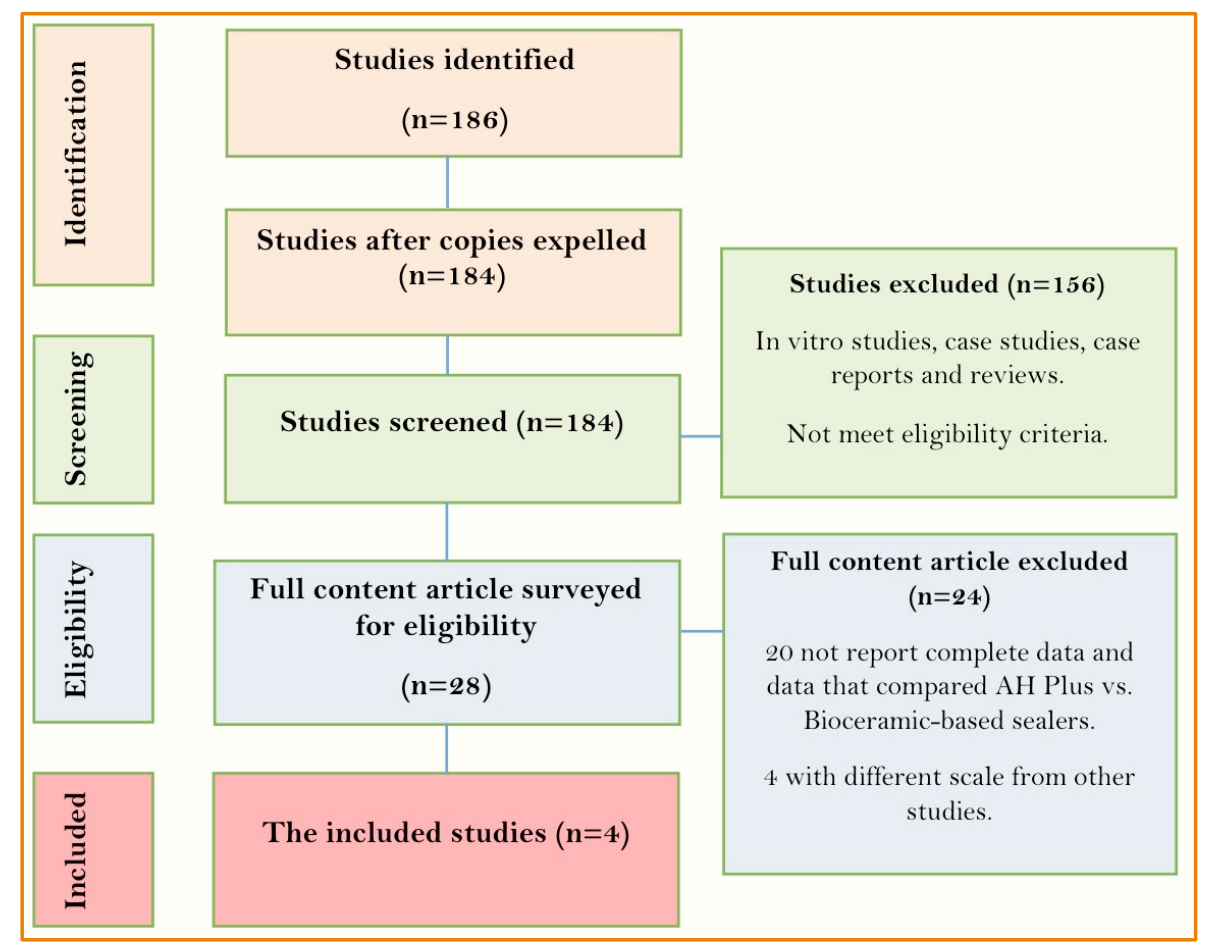

Figure 1. Study Attrition.

Sample Size

Therefore, four studies (randomized controlled trials) have been included. The number of patients a total was 121 . The mean age was 42.6 years. The number of teeth a total was 276 . Per patient received a visual analog scale (VAS) in all studies to record pain intensity 24 hours, 48 hours, 72 hours, and seven days after treatment (Table 2$)$. 
Table 2. Studies selected for systematic review and meta-analysis.

\begin{tabular}{|c|c|c|c|c|c|c|c|c|}
\hline Study & Design & No. o & Patients & Age* & No. of & Scale & Root Canal Sealers & Follow-up \\
\hline & & Male & Female & (Mean) & Teeth & & & \\
\hline$\overline{\text { Ferreira et al. [22] }}$ & RCT & & 57 & 41 & 60 & VAS & MTA & $24 \mathrm{~h}, 48 \mathrm{~h}$, and 7 \\
\hline & & 17 & 40 & & & & Fillapex, and EndoFill & days \\
\hline Fonseca et al. [23] & $\mathrm{RCT}$ & & 64 & 38 & 64 & VAS & AH Plus and Premixed & $24 \mathrm{~h}, 48 \mathrm{~h}$, and 7 \\
\hline & & 26 & 38 & & & & Sealer + BC & days \\
\hline Graunaite et al. [7] & RCT & & 61 & 49.5 & 122 & VAS & AH Plus Gutta-Percha & $24 \mathrm{~h}, 48 \mathrm{~h}$, and 7 \\
\hline & & 25 & 36 & & & & $\begin{array}{l}\text { Point, Total Fill Sealer } \\
\text { and a Total Fill BC } \\
\text { Point }\end{array}$ & days \\
\hline Paz et al. [24] & $\mathrm{RCT}$ & & $\begin{array}{l}30 \\
\text { NA }\end{array}$ & NA & 30 & VAS & AH Plus and BioRoot & $\begin{array}{l}24 \mathrm{~h}, 48 \mathrm{~h} \text {, and } 7 \\
\text { days }\end{array}$ \\
\hline
\end{tabular}

*In Years; RCT: Randomized Controlled Trial; VAS: Visual Analog Scale; NA: No information provided by the authors.

Bias Assessment

According to Cochrane Collaboration's tool, two studies had a total score of $4 / 6$, one study had a total score of $5 / 6$, and one study had a total score of $6 / 6$. This result showed a low bias risk in all studies and high quality (Table 3).

Table 3. Risk of bias assessment.

\begin{tabular}{|c|c|c|c|c|c|c|c|}
\hline Study & $\begin{array}{c}\text { Random } \\
\text { Sequence } \\
\text { Generation }\end{array}$ & $\begin{array}{c}\text { Allocation } \\
\text { Concealment }\end{array}$ & $\begin{array}{c}\text { Blinding of } \\
\text { Participants } \\
\text { and Personnel }\end{array}$ & $\begin{array}{l}\text { Blinding of } \\
\text { Outcome } \\
\text { Assessment }\end{array}$ & $\begin{array}{c}\text { Incomplete } \\
\text { Outcome } \\
\text { Data }\end{array}$ & $\begin{array}{l}\text { Selective } \\
\text { Reporting }\end{array}$ & $\begin{array}{l}\text { Total } \\
\text { Score }\end{array}$ \\
\hline Ferreira et al. [22] & & & & & & (?) & 5 \\
\hline Fonseca et al. [23] & & & ?) & & & (?) & 4 \\
\hline Graunaite et al. [7] & & & & & & & 6 \\
\hline Paz et al. [24] & & & P) & & & (?) & 4 \\
\hline
\end{tabular}

Low (+); Unclear (?); High (-).

Pain Scores after 24 Hours

Pain score was $(\mathrm{RR}=-0.20 ; 95 \% \mathrm{CI}-1.09-0.68 ; \mathrm{p}=0.65)$ among four studies and heterogeneity found $\left(\mathrm{I}^{2}=30.61 \% ; \mathrm{p}=0.19\right)$. This result showed that, after 24 hours, no statistically significant difference existed between the VAS scores for resin and bioceramic root canal sealers $(p=0.65)$, and no statistically significant difference was observed between the studies $(\mathrm{p}=0.19)$ (Figure 2).

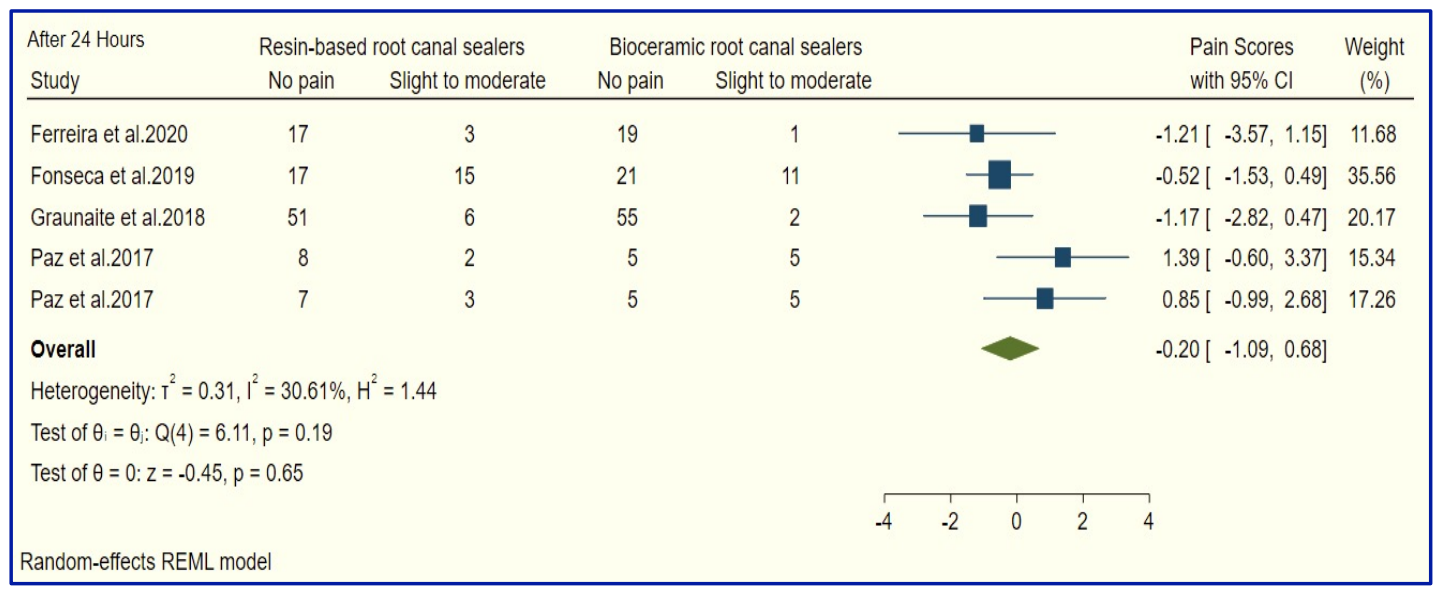

Figure 2. The forest plot showed postoperative pain after 24 hours. 
Pain Scores after 48 Hours

Pain score was $(\mathrm{RR}=-0.10 ; 95 \% \mathrm{CI}-1.44-1.23 ; \mathrm{p}=0.88)$ among 4 studies and heterogeneity found $\left(\mathrm{I}^{2}\right.$ $=46.61 \% ; \mathrm{p}=0.12)$. This result showed that after 48 hours, no statistically significant difference was observed between the VAS scores for the resin and bioceramic root canal sealers $(\mathrm{p}=0.88)$ and no statistically significant difference was observed between the studies $(\mathrm{p}=0.19)$ (Figure 3).

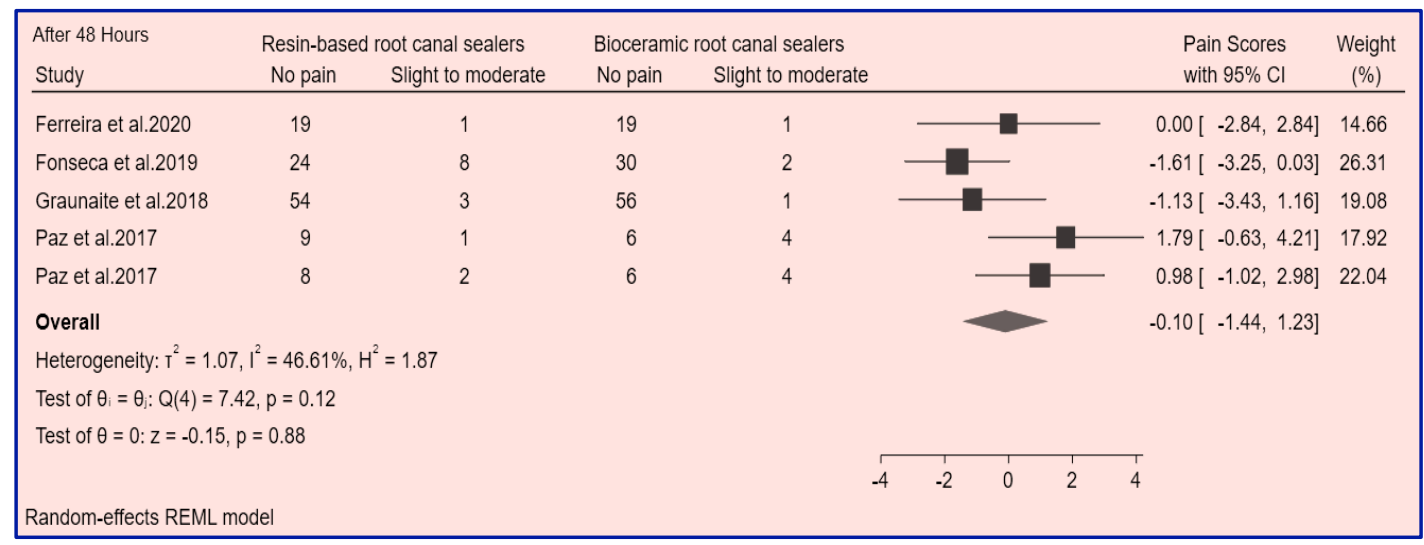

Figure 3. The forest plot showed postoperative pain after 48 hours.

Pain Scores after Seven Days

No pain or mild pain was reported in the studies after seven days.

Compared to Pain Scores after 24 and 48 Hours

Postoperative pain was felt more in the first 24 hours than after 48 hours, and the VAS score was higher after 24 hours vs. 48 hours.

\section{Discussion}

The local inflammatory response in periapical tissues causes postoperative pain in endodontics treatment $[25,26]$. In vivo studies have reported that reactive oxygen species can be directly associated with inflammatory pain [27]. If human pulp cells were treated in vitro with the root canal sealers, reactive oxygen species would increase from 4 to 7 times [28,29].

Resin-based AH Plus can also release toxic monomers such as diglicidyl ether bisphenol A, and the bioceramic sealer can have cytotoxic effects. But it should be noted that iRoot SP is less toxic than AH Plus [30,31]. Postoperative pain is triggered when the sealers' cytotoxicity implied contact with the periapical tissue. In gross overfilling cases, it can also be caused by the sealer [32,33].

No statistically significant difference in the present systematic review results and meta-analysis is shown in the postoperative pain observed at any of the points in time between the root canals obturated with resin-based and bioceramic sealers. It took 24 hours, 48 hours, 72 hours, and seven days to measure pain by 4 points. These time points have been used in studies to assess postoperative pain, as well as in vitro cytotoxicity tests [33]. Although differences between AH Plus and Total Fill have already been reported in vitro studies, no clinical differences have been observed. According to the present study results, the highest VAS score was reported 24 hours after surgery, which decreased after 48 hours. No pain was reported after seven days or was very mild. These results can be explained by the fact that to induce ROS formation, cytotoxic unpolymerized 
root canal sealers can play a role in the first 24 hours. The amount of pain varies from 24 hours to 48 hours in studies, but almost all results are the same. The quality of the selected studies was high in the present study, so this study's results can be cited. However, low postoperative pain scores can also be explained by not being overfilled. In this case, more studies are needed to achieve better results. Resin-based and bioceramic root canal sealers on the intensity and occurrence of postoperative pain could help the results of the present study.

\section{Conclusion}

Postoperative pain was low in patients requiring root canal retreatment and obturated with resinbased or bioceramic-based sealers without extrusion beyond the apex. No differences were observed 24 and 48 hours postoperatively between postoperative pain in resin-based and bioceramic root canal sealers. This means that resin-based and bioceramic root canal sealers act the same in incidence and postoperative pain severity. It will also require randomized controlled trial studies comparing resin-based and bioceramic root canal sealers with high sample sizes and seven days.

\section{Authors' Contributions}

\begin{tabular}{|c|c|c|}
\hline SJ & (D) https://orcid.org/0000-0003-3803-1235 & $\begin{array}{l}\text { Conceptualization, Methodology, Software, Validation, Formal Analysis, Investigation, Writing - } \\
\text { Original Draft, Writing - Review and Editing, Visualization and Supervision. }\end{array}$ \\
\hline MD & (iD) https://orcid.org/0000-0002-0622-4895 & Writing - Original Draft and Writing - Review and Editing. \\
\hline NN & (i) https://orcid.org/0000-0002-6365-6619 & Writing - Original Draft and Writing - Review and Editing. \\
\hline SJ & (iD) https://orcid.org/0000-0001-5196-0296 & Writing - Original Draft and Writing - Review and Editing. \\
\hline
\end{tabular}

\section{Financial Support}

None.

\section{Conflict of Interest}

The authors declare no conflicts of interest.

\section{Data Availability}

The data used to support the findings of this study can be made available upon request to the corresponding author.

\section{References}

[1] Sathorn C, Parashos P, Messer H. The prevalence of postoperative pain and flare-up in single-and multiple-visit endodontic treatment: a systematic review. Int Endod J 2008; 41(2):91-9.

https://doi.org/10.1111/j.1365-2591.2007.01316.x

[2] Cunha TC, de Souza Matos F, Paranhos LR, de Macedo Bernardino Í, Moura CC. Influence of glide path kinematics during endodontic treatment on the occurrence and intensity of intraoperative and postoperative pain: a systematic review of randomized clinical trials. BMC Oral Health 2020; 20(1):1-13.

https://doi.org/10.1186/s12903-020-01164-w

[3] Sudhakar K, Kumar CS, Lavanya A, Swapna S. Influence of instrument design on post-operative pain in single-visit root canal treatment with Protaper Next and $\mathrm{V}$ taper $2 \mathrm{H}$ rotary systems in symptomatic irreversible pulpitis of multirooted teeth-A randomized clinical trial. J Clin Transl Res 2020; 5(5):230-5. https://doi.org/10.18053/jctres.05.202005.002

[4] Nagendrababu V, Gutmann JL. Factors associated with postobturation pain following single-visit nonsurgical root canal treatment: A systematic review. Quintessence Int 2017; 48(3):193-208. https://doi.org/10.3290/j.qi.a36894

[5] Thakur S, Emil J, Paulaian B. Evaluation of mineral trioxide aggregate as root canal sealer: A clinical study. J Conserv Dent 2013; 16(6):494-8. https://doi.org/10.4103/0972-0707.120944

[6] Lee DS, Lim MJ, Choi Y, Rosa V, Hong CU, Min KS. Tooth discoloration induced by a novel mineral trioxide aggregate-based root canal sealer. Eur J Dent 2016; 10(3):403-7. https://doi.org/10.4103/1305-7456.184165

[7] Graunaite I, Skucaite N, Lodiene G, Agentiene I, Machiulskiene V. Effect of resin-based and bioceramic root canal sealers on postoperative pain: a split-mouth randomized controlled trial. J Endod 2018; 44(5):689-93. https://doi.org/10.1016/j.joen.2018.02.010 
[8] Zhang W, Peng B. Tissue reactions after subcutaneous and intraosseous implantation of iRoot SP, MTA and AH Plus. Dent Mater J 2015; 34(6):774-80. https://doi.org/10.4012/dmj.2014-271

[9] de Miranda Candeiro GT, Correia FC, Duarte MA, Ribeiro-Siqueira DC, Gavini G. Evaluation of radiopacity, pH, release of calcium ions, and flow of a bioceramic root canal sealer. J Endod 2012; 38(6):842-5. https://doi.org/10.1016/j.joen.2012.02.029

[10] Zordan-Bronzel CL, Torres FF, Tanomaru-Filho M, Chávez-Andrade GM, Bosso-Martelo R, Guerreiro-Tanomaru JM. Evaluation of physicochemical properties of a new calcium silicate-based sealer, Bio-C Sealer. J Endod 2019; 45(10):1248-52. https://doi.org/10.1016/j.joen.2019.07.006

[11] Lee JK, Kwak SW, Ha JH, Lee W, Kim HC. Physicochemical properties of epoxy resin-based and bioceramic-based root canal sealers. Bioinorg Chem Appl 2017; 2017:2582849. https://doi.org/10.1155/2017/2582849

[12] Poggio C, Dagna A, Ceci M, Meravini MV, Colombo M, Pietrocola G. Solubility and pH of bioceramic root canal sealers: a comparative study. J Clin Exp Dent 2017; 9(10):e1189-94. https://doi.org/10.4317/jced.54040

[13] Zhang W, Li Z, Peng B. Ex vivo cytotoxicity of a new calcium silicate-based canal filling material. Int Endod J 2010; 43(9):769-74. https://doi.org/10.1111/j.1365-2591.2010.01733.x

[14] Jung S, Libricht V, Sielker S, Hanisch MR, Schäfer E, Dammaschke T. Evaluation of the biocompatibility of root canal sealers on human periodontal ligament cells ex vivo. Odontology 2019; 107(1):54-63. https://doi.org/10.1007/s10266-018-0380-3

[15] Almeida LH, Moraes RR, Morgental RD, Pappen FG. Are premixed calcium silicate-based endodontic sealers comparable to conventional materials? A systematic review of in vitro studies. J Endod 2017; 43(4):527-35. https://doi.org/10.1016/j.joen.2016.11.019

[16] Lee JK, Kim S, Lee S, Kim HC, Kim E. In vitro comparison of biocompatibility of calcium silicate-based root canal sealers. Materials 2019; 12(15):2411. https://doi.org/10.3390/ma12152411

[17] Ozkocak I, Sonat B. Evaluation of effects on the adhesion of various root canal sealers after Er: YAG laser and irrigants are used on the dentin surface. J Endod 2015; 41(8):1331-6. https://doi.org/10.1016/j.joen.2015.03.004

[18] Crozeta BM, Lopes FC, Silva RM, Silva-Sousa YT, Moretti LF, Sousa-Neto MD. Retreatability of BC Sealer and AH Plus root canal sealers using new supplementary instrumentation protocol during non-surgical endodontic retreatment. Clin Oral Investig 202 1; 25(3):891-9. https://doi.org/10.1007/s00784-020-03376-4

[19] Graunaite I, Lodiene G, Arandarcikaite O, Pukalskas A, Machiulskiene V. Leachables and cytotoxicity of root canal sealers. J Oral Sci 2018; 60(3):381-7. https://doi.org/10.2334/josnusd.17-0173

[20] Moher D, Liberati A, Tetzlaff J, Altman DG, Altman D, Antes G, et al. Preferred reporting items for systematic reviews and meta-analyses: The PRISMA statement (Chinese edition). Chin J Integr Med 2009; 7(9):889-96. https://doi.org/10.3736/jcim20090918

[21] Higgins JP, Altman DG, Gøtzsche PC, Jüni P, Moher D, Oxman AD, et al. The Cochrane Collaboration's tool for assessing risk of bias in randomised trials. BMJ 2011; 343:d5928. https://doi.org/10.1136/bmj.d5928

[22] Ferreira ND, Gollo EK, Boscato N, Arias A, Silva EJ. Postoperative pain after root canal filling with different endodontic sealers: a randomized clinical trial. Braz Oral Res 2020; 34.

https://doi.org/10.1590/1807-3107bor-2020.vol34.0069

[23] Fonseca B, Coelho MS, da Silveira Bueno CE, Fontana CE, De Martin AS, Rocha DG. Assessment of extrusion and postoperative pain of a bioceramic and resin-based root canal sealer. Eur J Dent 2019; 13(3):343-8. https://doi.org/10.1055/s-0039-3399457

[24] Paz AB. Evaluation of postoperative pain after using bioceramic materials as endodontic sealers: randomized control clinical trial (Doctoral dissertation). 2017.

[25] West AP, Shadel GS, Ghosh S. Mitochondria in innate immune responses. Nat Rev Immunol 2011; 11(6):389-402. https://doi.org/10.1038/nri2975

[26] West AP, Shadel GS. Mitochondrial DNA in innate immune responses and inflammatory pathology. Nat Rev Immunol 2017; 17(6):363-75. https://doi.org/10.1038/nri.2017.21

[27] Vengerfeldt V, Mändar R, Saag M, Piir A, Kullisaar T. Oxidative stress in patients with endodontic pathologies. J Pain Res 2017; 10:2031-40. https://doi.org/10.2147/JPR.S141366

[28] Silva GO, Cavalcanti BN, Oliveira TR, Bin CV, Camargo SE, Camargo CH. Cytotoxicity and genotoxicity of natural resin-based experimental endodontic sealers. Clin Oral Investig 2016; 20(4):815-9. https://doi.org/10.1007/s00784-015-1567-4

[29] Fonseca DA, Paula AB, Marto CM, Coelho A, Paulo S, Martinho JP, et al. Biocompatibility of root canal sealers: A systematic review of in vitro and in vivo studies. Materials 2019; 12(24):4113. https://doi.org/10.3390/ma12244113

[30] Lodienė G, Kopperud HM, Ørstavik D, Bruzell EM. Detection of leachables and cytotoxicity after exposure to methacrylate-and epoxy-based root canal sealers in vitro. Eur J Oral Sci 2013; 121(5):488-96. https://doi.org/10.1111/eos.12065

[31] Rosen E, Goldberger T, Taschieri S, Del Fabbro M, Corbella S, Tsesis I. The prognosis of altered sensation after extrusion of root canal filling materials: a systematic review of the literature. J Endod 2016; 42(6):873-9. https://doi.org/10.1016/j.joen.2016.03.018 
[32] Okiji T. Non-Surgical Root Canal Treatment Case V: Mandibular Premolar. In: Komabayashi T. Clinical Cases in Endodontics. London: Wiley Blackwell; 2017; pp. 79-90.

[33] Victoria-Escandell A, Ibañez-Cabellos JS, de Cutanda SB, Berenguer-Pascual E, Beltrán-García J, García-López E, et al. Cellular responses in human dental pulp stem cells treated with three endodontic materials. Stem Cells Int 2017; 2017:8920356. https://doi.org/10.1155/2017/8920356 